\title{
Pentingnya Ukuran Kinerja Nonfinansial dalam Balanced Scorecard, Komitmen Organisasi, dan Kinerja Manajerial
}

\author{
Praja Hadi Saputra ${ }^{\mathrm{a}^{*}}$, Hamid Bone ${ }^{\mathrm{b}}$ and Linayati Lestari ${ }^{\mathrm{c}}$ \\ à Departemen Manajemen, Universitas Muhammadiyah Kalimantan Timur, praja.hs@umkt.ac.id, Indonesia \\ ${ }^{\mathrm{b}}$ Departemen Akuntansi, Universitas Mulawarman, hamid.bone@feb.unmu.ac.id, Indonesia \\ ${ }^{c}$ Departemen Ilmu Politik, Universitas Riau Kepulauan, linayatilestari@yahoo.com, Indonesia
}

\begin{abstract}
This study investigates the role of the degree of importance of using nonfinancial performance measures (in Balanced Scorecard) by superiors for performance evaluation in influencing employee performance through organizational commitment. This study adopted a quantitative research design and conducted a cross-sectional survey by questionnaire to collect responses from 118 local managers in Samarinda, Indonesia. Based on PLS analysis, the results of this study indicate that the use of nonfinancial measures in Balanced Scorecard for performance evaluation is significantly affect employee organizational commitment and directly affect managerial performance through organizational commitment. The results also prove that organizational commitment has a mediation role in the relationship between nonfinancial measures and performance. This study provides valuable insight that the degree of importance of the use of nonfinancial measures by superiors to evaluate performance can improve employee commitment and performance. Practically, the results provide an overview for superiors to be more comprehensive in developing a performance measurement system because the system has a crucial role in influencing employee behavior.
\end{abstract}

Keywords: nonfinancial measures, balanced scorecard, organizational commitment, managerial performance

\footnotetext{
*Corresponding author. E-mail: praja.hs@umkt.ac.id
} 


\section{Pendahuluan}

Korelasi antara sistem pengukuran kinerja dengan perilaku anggota organisasi merupakan topik yang saat ini telah menjadi tumpuan perhatian dalam penelitian-penelitian bisnis khususnya akuntansi manajemen. Penelitian tentang sistem pengukuran kinerja juga telah mengalami perluasan cakupan pada persepktif individual sebagai perbandingan terhadap perspektif organisasional. Hal ini dikarenakan sistem pengukuran kinerja yang diaplikasikan oleh atasan terindikasi mampu mempengaruhi perilaku bawahan atau karyawan yang nantinya mengarah pada peningkatan (penurunan) kinerja yang dihasilkan.

Para ahli meyakini bahwa, dalam literatur akuntansi manajemen, sistem pengukuran kinerja memainkan peranan yang sangat penting khususnya pada peningkatan kinerja individual di sebuah organisasi bisnis (Hall, 2008; Kaplan \& Norton, 1996; Lau \& Roopnarain, 2014). Peranan lain dari sistem pengukuran kinerja adalah mulai dari menerjemahkan strategi organisasi ke dalam tindakan yang mengarah pada hasil yang diinginkan hingga memotivasi para individu organisasi (karyawan) untuk mencapai target yang ditentukan. Sehingga, tidak jarang para pimpinan (manajemen puncak) organisasi merumuskan sistem pengukuran kinerja secara legih hati-hati serta komprehensif. Hal tersebut dilakukan agar evaluasi kinerja dapat relevan dengan perencanaan organisasi dan mampu mendorong karyawan untuk berperilaku atau bertindak yang mengarah pada pencapaian hasil sesuai perencanaan.

Secara spesifik, para ahli di bidang sistem pengendalian manajemen telah melakukan penelitianpenelitian mengenai peranan dari sistem evaluasi kinerja dalam organisasi atau perusahaan (Behn, 2003; Chenhall \& Moers, 2015; Davis \& Albright, 2004; Grafton, Lillis, \& Widener, 2010). Terbaru, sebuah perkembangan perspektif penelitian akuntansi manajemen juga menekankan pentingnya sistem pengukuran kinerja untuk pergerakan inovasi sebuah perusahaan (Bedford, Bisbe, \& Sweeney, 2019). Sebuah reviu literatur follow-up yang dilakukan oleh Chenhall \& Langfield-Smith (2007) menjernihkan pemahaman bahwa pengembangan sistem pengukuran kinerja dapat dilakukan dengan pendekatan yang berbeda-beda (sesuai kebutuhan organisasi) serta menyesuaikan dengan ketidakpastian dalam lingkungan bisnis yang dihadapi. Desain sistem pengukuran kinerja yang digunakan organisasi seyogyanya dibuat lebih kompleks dan terperinci atau, dengan kata lain, lebih komprehensif.
Ittner, Larcker, \& Randall (2003) mendefinisikan sebuah sistem evaluasi kinerja yang komprehensif merupakan sistem yang dipercaya dapat memenuhi berbagai tujuan dari pengukuran kinerja itu sendiri karena menggunakan multiple informasi yang berkaitan dengan ukuran-ukuran kinerja, baik itu finansial maupun nonfinansial (NF). Salah satu contoh sistem pengukuran kinerja komprehensif yang selalu menjadi fokus utama dalam penelitian bidang akuntansi manajemen selama (kurang-lebih) dua dekade terakhir adalah Balanced Scorecard (lihat Hoque, 2014). Sistem pengukuran kinerja berbasis Balanced Scorecard dianggap lebih komprehensif kerena merupakan sistem yang digunakan untuk evaluasi kinerja yang menyediakan ukuran-ukuran kinerja bervariasi yaitu ukuran finansial dan nonfinansial (Hoque, 2014; Malina \& Selto, 2004). Oleh karena itu, fokus dari studi ini adalah pada ukuran kinerja yang termasuk dalam kategori perspektif Balanced Scorecard.

Beberapa penelitian dan literatur terdahulu telah menemukan berbagai macam bukti empiris serta memberikan pemahaman bahwa ukuran-ukuran dalam sistem evaluasi kinerja memiliki hubungan serta pengaruh terhadap luaran level organisasi, seperti kinerja organisasi (Davis \& Albright, 2004; Hoque \& James, 2000), strategi perusahaan (Chenhall, 2005; Kaplan \& Norton, 1996), serta kapabilitas organisasi (Grafton et al., 2010). Selain itu, para ahli di bidang sistem pengukuran kinerja multidimensi juga telah memperluas fokusnya dari tingkat organisasi ke tingkat individual (Hall, 2008; Hartmann \& Slapničar, 2009; Lau, 2011; Lau \& Roopnarain, 2014). Hal tersebut kemudian memotivasi peneliti untuk turut menginvestigasi peranan ukuran kinerja (dari persepsi tingkat kepentingannya) dalam evaluasi kinerja terhadap perilaku dan luaran kinerja individu dalam organisasi.

Sebagai sebuah sistem evaluasi kinerja komprehensif, Balanced Scorecard memiliki berbagai ukuran beragam atau multiple measures yang digunakan dalam mengukur kinerja bawahan. Ukuranukuran tersebut dapat diklasifikasikan menjadi dua yaitu ukuran finansial dan ukuran nonfinansial (Kaplan \& Norton, 1996). Meskipun sudah diketahui secara pasti, secara teoritis dan empiris, bahwa sistem evaluasi kinerja memiliki pengaruh terhadap perilaku individu dalam organisasi, namun belum diketahui bagaimana pengaruh tersebut dapat dihasilakan dan menimbulkan beberapa pertanyaan (1) Apakah pengaruhnya berasal dari ukuran kinerja finansial? (2) Atau kah berasal dari ukuran nonfinansial? 
Lau (2011) memberikan sebuah argumentasi yang relevan untuk menjawab pertanyaan substantif di atas, ia mengungkapkan bahwa sebuah penelitian yang lebih lanjut mengenai peran dari ukuran-ukuran kinerja (secara terpisah atau keduanya) dalam mempengaruhi perilaku dan kinerja individu perlu dilakukan. Oleh karena itu, penelitian bertujuan melakukan follow-up riset empiris tentang peranan salah satu ukuran kinerja, yaitu nonfinansial, yang digunakan dalam evaluasi kinerja dalam mempengaruhi perilaku kognitif dan peningkatan kinerja karyawan. Penelitian ini hanya berfokus pada peranan ukuran kinerja nonfinansial karena ukuran tersebut dianggap lebih merepresentasikan ukuran kinerja untuk semua unit dalam organisasi. Hal ini berdasarkan pertimbangan penelitian-penelitian terdahulu yang menganggap bahwa penggunaan ukuran finansial saja dalam pengukuran kinerja dapat memiliki keterbatasan. Implimentasi ukuran kinerja nonfinansial (seperti inovasi produk dan loyalitas konsumen) diyakini mampu mengindikasikan capaian kinerja keuangan organisasi di masa depan serta membangun sinergi antara tujuan jangka panjang organsiasi (Kaplan, 1996, Lau, 2011).

Lau \& Roopnarain (2014) mengungkapkan bahwa penggunaan ukuran nonfinansial dianggap sebagai perspektif ukuran kinerja paling diterima secara umum di semua departemen dan jenis organisasi karena ukuran nonfinansial memiliki fleksibilitas yang dapat disesuaikan dengan kondisi organisasi bahkan untuk variasi unit bisnis dalam organisasi. Berbeda dengan ukuran finansial yang memiliki kekurangan tidak dapat diimplementasikan pada lingkungan bisnis yang dinamis dan banyak ketidakpastian (Chow \& Van Der Stede, 2006).

Konsekuensi dari penggunaan ukuran nonfinansial yang menjadi fokus penelitian ini juga mengarah pada faktor individu terpenting dalam sebuah organisasi yaitu komitmen organisasi. Komitmen organiasi merupakan faktor esensial dan secara positif mempengaruhi perilaku yang menguntungkan organisasi seperti usaha karyawan, retensi, serta peningkatan kinerja (Sholihin \& Pike, 2010). Karyawan yang kinerjanya diukur berdasarkan pengukuran kinerhja yang komprehensif, memiliki variasi ukuran dari kinerja nonfinansial, akan merasa bahwa kinerja mereka diukur secara menyeluruh atau tidak hanya melihat dari capaian kinerja keuangan saja. Hal ini selanjutnya dapat menstimulasi komitmen para karyawan kepada organisasi tempat mereka bekerja karena mereka merasa puas terhadap system pengukuran yang digunakan (Saputra \& Riyanto, 2017).
Kontribusi dari penelitian ini adalah memberikan bukti empiris bahwa melalui observasi pada peran penggunaan ukuran kinerja pada evaluasi kinerja, akan memberikan pemahaman bagi karyawan mengapa kinerja perlu diukur serta dapat mengetahui bagaimana tujuan individu serta tim dalam organiasi mencapai target (ukuran) yang ditetapkan organisasi. Hal tersebut sejalan dengan pemikiran dalam penelitian Ukko, Tenhunen, \& Rantanen (2007) yang menyebutkan bahwa karyawan perlu untuk mengetahui bagaimana persepsi mereka terkait ukuran kinerja yang digunakan dalam evaluasi kinerja karena dapat mempengaruhi bagaimana mereka berprilaku. Secara empiris, melalui penelitian ini, kita mampu mengetahui bagaimana ukuran nonfinansial dalam Balanced Scorecard yang digunakan dalam evaluasi kinerja dapat mempengaruhi komitmen organiasi serta secara tidak langsung mampu meningkatkan kinerja melalui komitmen organisasi yang dimiliki oleh karyawan.

\section{Kajian Teori dan Pengembangan Hipotesis}

\section{Teori penetapan tujuan (Goal-setting theory)}

Penelitian ini menggunakan teori penetapan tujuan (Goal-setting theory) untuk mendeskripsikan peranan dari penggunaan ukuran kinerja nonfinansial dalam mengevaluasi kinerja bawahan (manajer). Teori penetapan tujuan merupakan bagian dari jenis teori psikologi positif yang sering digunakan pada penelitian-penelitian bisnis tak terkecuali pada penelitian akuntansi manajemen (Lau, 2011). Sejatinya, teori ini adalah satu dari berbagai macam teori yang dikembangkan dari kerangka pikir motivasi individu. Locke \& Latham (1991) mengemukakan, Goal-Setting Theory memiliki asumsi bahwa segala tindakan manusia (human action) diarahkan oleh tujuan serta niat untuk sejalan dengan pencapaian tujuan yang telah ditetapkan.

Penetapan tujuan atau goal-setting memiliki dua pengaruh direksional terhadap perilaku individu. Pertama, tujuan yang ditentukan akan mengorientasikan individu pada aktivitas-aktivitas yang relevan dengan pencapaian tujuan. Kedua, penetapan tujuan akan menstimulasi potensi dan pengetahuan yang ada dalam diri individu untuk digunakan pada pencapaian tujuan yang telah ditetapkan. Hal ini sejalan dengan penggunaan ukuran-ukuran kinerja pada evaluasi kinerja individu dalam organisasi. Ukuran kinerja yang ada merupakan target yang ditentukan agar individu yang kinerjanya 
dievaluasi dapat mengarahkan segala upaya dan kemampuan mereka untuk memenuhi kriteria atau ukuran kinerja yang ditetapkan.

\section{Pengembangan Hipotesis}

Proses dalam pengukuran kinerja karyawan merupakan bagian penting dalam menentukan bagaimana karyawan tersebut berperilaku sebagai respon dari sistem evaluasi kinerja yang digunakan untuk mengukur kinerja mereka. Aplikasi ukuran kinerja (seperti nonfinansial) pada evaluasi kinerja yang mencakup berbagai macam perspektif ukuran (sesuai perspektif dalam Balanced Scorecard) dianggap oleh para karyawan sebagai evaluasi kinerja yang adil karena mengukur kinerja mereka secara menyeluruh.

Karyawan yang menganggap bahwa kinerja mereka diukur secara menyeluruh, tidak hanya berdasarkan ukuran finansial saja tetapi juga ukuran nonfinansial, akan merasa puas dan percaya kepada atasan mereka (Lau \& Oger, 2012). Hal ini akan membuat karyawan menunjukkan perilaku komitmen pada organisasi serta mengarah pada peningkatan kinerja. Pernyataan tersebut sejalan dengan penelitian yang dilakukan oleh Lau \& Moser (2008) terhadap 296 kepala departemen dari 103 perusahaan manufaktur di Britania Raya (U.K) yang menemukan bahwa, penggunaan ukuran kinerja nonfinansial sebagai kriteria evaluasi kinerja dapat bermanfaat untuk meningkatkan komitmen karyawan terhadap organisasi serta mempengaruhi motivasi mereka menigkatkan kinerja. Oleh karena itu, karyawan yang memiliki persepsi bahwa penggunaan ukuran nonfinansial dalam evaluasi kinerja adalah penting akan meningkatkan komitmen dan kinerja mereka dalam organisasi. Berdasarkan uraian di atas, peneltian ini mengusulkan hipotesis untuk diuji sebagai berikut:

$\mathrm{H}_{1 \mathrm{a}}$ : Persepsi karyawan mengenai tingkat kepentingan penggunaan ukuran kinerja nonfinansial Balanced Scorecard dalam evaluasi kinerja memiliki pengaruh terhadap komitmen organisasi yang dimiliki oleh karyawan

$\mathrm{H}_{1 \mathrm{~b}}$ : Persepsi karyawan mengenai tingkat kepentingan penggunaan ukuran kinerja nonfinansial Balanced Scorecard dalam evaluasi kinerja memiliki pengaruh terhadap kinerja manajerial (karyawan)

Komitmen terhadap organisasi merupakan salah satu elemen terkuat yang digunakan untuk mengidentifikas keterlibatan individu dalam sebuah organisasi. Individu yang berkomitmen tentunya akan memberikan "pengorbanan" untuk kepentingan organiasi dan berperilaku untuk meningkatkan keuntungan bagi organisasi. Jaros, Jermier, Koehler, \& Sincich (1993) menerangkan bahwa komitemen organisasi (khususnya komitemen afektif) melibatkan pembentukan ikatan emosional antara individu dengan organisasi dan akan menempatkan individu tersebut pada tanggung jawab terhadap organisasinya termasuk peningkatan kinerja. Beberapa studi tentang komitmen organisasi juga memberikan bukti bahwa komitmen afektif berhubungan secara positif terhadap kinerja manajerial atau kinerja para karyawan (Lau \& Moser, 2008; Meyer, Paunonen, Ian, Goffin, \& Jackson, 1989). Berdasarkan penjelasan ini, maka peneliti mengusulkan hipotesis sebagai berikut:

$\mathrm{H}_{2}$ : Komitmen afektif yang dimiliki oleh karyawan untuk organisasinya berpengaruh positif terhadap kinerja manajerial (karyawan).

Seperti yang telah didiskusikan pada bagian sebelumnya, ukuran nonfinansial yang dianggap penting penggunaannya kemungkinan memiliki perngaruh terhadap komitmen organisasi yang nantinya akan berpengaruh terhadap kinerja manajerial (karyawan). Hal ini mengindikasikan bahwa selain pengaruh langsung, ukuran nonfinansial juga memiliki peranan untuk mempengaruhi kinerja para karyawan secara tidak langsung atau melalui komitmen karyawan terhadap organisasi mereka. Lau \& Moser (2008) menemukan bahwa ukuran kinerja nonfinansial yang digunakan dalam sistem pengukuran kinerja memiliki sifat yang berkapasitas untuk mengukur berbagai dimensi kinerja karyawan dari perspektif yang luas. Mereka berpendapat jika manajer yang kinerjanya dievaluasi berdasarakan ukuran nonfinansial cenderung menunjukkan sikapsikap yang menguntungkan organisasi seperti komitemen organsiasi yang diobservasi dalam penelitian ini. Selanjutnya, karyawan yang memiliki komitmen organsiasi yang tinggi akibat dari persepsi pentingnya penggunaan ukuran kinerja nonfinansial akan menunjukkan sikap aktif dalam keterlibatannya di organisasi serta berkontribusi dalam peningkatan organisasi dengan memberikan kinerja individu terbaik mereka.

Dengan kata lain, berdasarkan deskripsi hubungan antara penggunaan ukuran nonfinansial, komitmen organsiasi, dan kinerja manajerial diatas, dapat dijelaskan bahwa terdapat peranan variabel komitmen organisasi yang memediasi hubungan antara penggunaan ukuran kinerja nonfinansial dengan kinerja manajerial. Oleh karena itu, studi ini mengajukan hipotesis mediasi sebagai berikut: 
$\mathrm{H}_{3}$ : Pengaruh tingkat kepentingan penggunaan ukuran nonfinansial Balanced Scorecard dalam evaluasi kinerja terhadap kinerja manajerial dimediasi oleh komitmen organisasi afektif yang dimiliki karyawan.

Gambar 1 adalah model penelitian yang digunakan unuk mengilustrasikan hubungan antar variabel dan hipotesis penelitian yang akan diuji untuk mengetahui hubungan dari variabel-variabel observasian dalam penelitian ini.

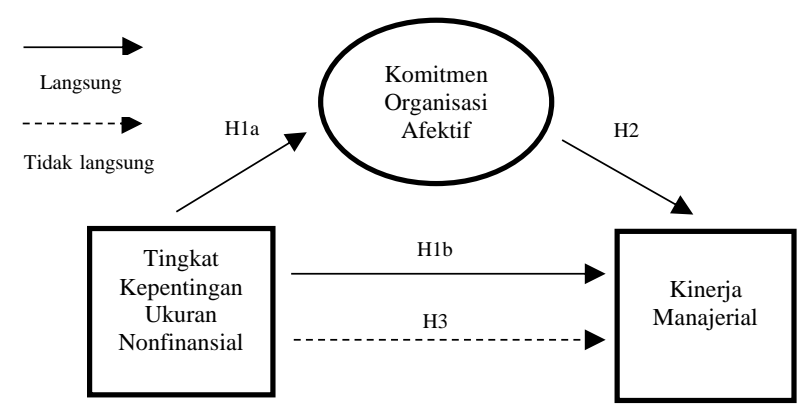

Gambar 1. Model Penelitian

\section{Metode Penelitian}

\section{Desain dan sampel penelitian}

Penelitian ini mengadopsi sebuah desain penelitian kuantitatif yang dilakukan dengan metode survei secara cross-sectional untuk pengumpulan data penelitian. Para responden yang berpartisipasi sebagai sampel penelitian adalah para manajer regional dan sedang menempuh pendidikan magister manajemen pada salah satu kampus di Kota Samarinda. Supriyadi (2010) mengatakan bahwa penggunaan manajer yang juga part-time student dianggap representatif karena mereka sesungguhnya adalah para pelaku bisnis di dunia nyata.

Pendistribusian kuesioner dilakukan kepada para manajer yang memiliki area tanggung jawab di tempat mereka bekerja serta telah menempuh perkuliahan Sistem Pengendalian Manajemen di Kampus mereka. Saputra \& Riyanto (2017) menjelaskan bahwa pemilihan kriteria sampel manajer yang bertanggung jawab atas suatu unit atau departemen dianggap tepat untuk mewakili sampel karena mereka memiliki pengalaman praktek sebagai seorang profesional serta familiar dengan lingkungan bisnis dan area tanggung jawabnya.
Studi ini menggunakan beberapa pendekatan dalam survei untuk menghindari kendala teknis seperti tingkat respon yang rendah. Pertama, peneliti menggunakan insentif yang bersifat non-moneter sebagai bentuk apresiasi keikutsertaan responden dalam survei yang dilakukan. Kedua, penggunaan desain kuesiner yang ringkas dan jelas beserta tampilan menarik ditiap lembarannya sehingga responden tidak jenuh untuk mengisi dan hanya membutuhkan waktu 5 sampai 10 menit.

Sebanyak 156 manajer bersedia untuk ikut dalam survei sebagai sampel penelitian. Namun, hanya 118 respon yang dapat digunakan untuk analisis lebih lanjut. Hal ini mengindikasikan tingkat respon yang cukup tinggi yaitu sebesar $75,64 \%$. Jumlah tersebut dianggap cukup memenuhi asumsi untuk digunakan pada analisis statistik penelitian. Data demografi karakteristik penelitian mengindikasikan bahwa mayoritas responden memiliki bekerja lebih dari 5 tahun yaitu sebanyak 65 orang dengan kelompok usia rata-rata 35 tahun ke atas. Selain itu, dari total 118 manajer, sebanyak 71 orang laki-laki dan 47 lainnya dalah perempuan. Para manajer berasal dari berbagai industri yang berbeda seperti manufaktur, ekspedisi, otomotif, pertambangan, minyak dan gas, serta jasa keuangan dan perbankan. Keanekaragaam industri asal para responden tersebut semakin memberikan kekuatan pemilihan sampel penelitian karena karakteristik ukuran Balanced Scorecard yang digunakan dalam penelitian ini juga fit terhadap berbagai jenis bisnis.

\section{Definisi operasional dan instrumen pengukuran variable}

Persepsi tingkat kepentingan penggunaan ukuran nonfinansial (NF) dalam evaluasi kinerja yang merupakan variabel independen penelitian ini adalah persepsi individu manajer (karyawan) mengenai seberapa pentingnya ukuran kinerja nonfinansial digunakan untuk evaluasi kinerja mereka. Variabel tingkat kepentingan ukuran nonfinansial (X) dalam penelitian ini diukur dengan instrumen adopsian dari penelitian Lau \& Moser (2008) yang berdasarkan perspektif nonfinansial pada Balanced Scorecard (BSC). Dari tiga perspektif nonfinansial, peneliti hanya menggunakan perspektif pembelajaran dan pertumbuhan karena merupakan driving force dari BSC. Konstruk ini (begitu juga dengan konstruk lainnya) kemudian diukur dengan menggunakan lima item pengukuran berdasarkan poin dalam skala Likert. 
Selanjutnya adalah variabel komitment organisasi (Kom) yang mengukur bagaimana sikap komitmen yang dimiliki oleh responden (manajer) terhadap organsiasi mereka. Komitmen organisasi dalam penelitian ini selanjutnya diukur berdasarkan shortform scale yang dikembangkan oleh Mowday, Steers, \& Porter (1979) dan terdiri dari 9 indikator yang meminta responden untuk memberikan tanggapan serta tingkat kesetujuan mereka pada item-item yang ada pada instrumen.

Variabel kinerja manajerial (Kin) adalah variabel dependen (Y) penelitian yang merupakan hasil luaran dari kerja yang dilakukan oleh individu organisasi berdasarkan kemampuan mereka. Kinerja manajerial dalam penelitian ini sama dengan konsep kinerja yang diterangkan oleh Mahoney, Jerdee, \& Carroll (1965) yaitu hasil kerja yang menjadi luaran individu sebagai bentuk dari motivasi kerja dan peningkatan kerja mereka. Konsep kinerja manajerial ini juga sudah sering dugunakan dalam penelitian akuntansi manajemen seperti pada penelitian Hall (2008) dan Lau (2011). Kinerja manajerial diukur berdasarkan instrumen self-rating dari Mahoney, Jerdee, \& Carroll (1965) yang terdiri dari 9 item subdimensi dan kinerja keseluruhan.

\section{Teknik analisis data}

Studi ini mengaplikasikan alat analisis Partial Least Square (PLS) sebagai model statistik untuk menganalisis data yang sudah dikumpulkan dan dioperasikan menggunakan software WarpPLS 3.0. Alasan penggunaan analisis ini karena PLS dianggap tepat untuk menguji model yang cukup kompleks dalam sebuah penelitian. PLS merupakan alat analisis yang relevan jika ingin menguji model penelitian kompleks secara simultan serta dapat meningkatkan estimasi dan validitas kesimpulan statistiknya (Hair et al., 2016; Kock, 2013). Selain itu, keunggulan menggunakan PLS adalah analisis ini memiliki kemampuan untuk menangani penelitian dengan ukuran sampel yang tergolong kecil dan tidak perlu menggunakan asumsi distribusional apapun.

Model penelitian ini cukup kompleks karena terdiri atas variabel independen, dependen, dan mediasi serta memiliki ukuran sampel sebanyak 118 sehingga memenuhi syarat untuk pemodelan analisis PLS. Proses analisis dalam pemodelan PLS dilakukan berdasarkan dua tahapan. Pertama, evaluasi dan analisis terhadap model pengukuran (outer model) untuk pengujian validitas dan reliabilitas konstruk penelitian. Tahap selanjutnya adalah melakukan evaluasi terhadap model struktural (inner model) penelitian untuk tujuan pengujian hipotesis.

\section{Hasil dan Pembahasan}

\section{Hasil}

Analisis statistik deskriptif melaporkan tentang gambaran umum mengenai data penelitian sehingga menerangkan secara rinci tentang data yang sudah dikumpulkan. Tabel 1 menunjukkan bahwa anggapan responden pada pentingnya penggunaan ukuran kinerja nonfinansial dalam evaluasi kinerja adalah sangat tinggi. Hal ini terlihat dari nilai rata-rata tingkat kepentingan penggunaan ukuran nonfinansial (NF) berada diatas nilai tengah kisaran teoritis yaitu 19,46. Untuk komitmen organisasi afektif terhadap organisasi (Kom), jawaban responden menunjukkan komitmen yang cukup memadai dengan nilai 30,42 yang berada dalam kisaran nilai teoritisnya. Selanjutnya, untuk kinerja yang dicapai (Kin) juga cukup tinggi dengan nilai rata-rata 32,40 yang lebih besar dibandingkan nilai tengah kisaran teoritisnya.

Tabel 1

Statistik Deskriptif

\begin{tabular}{lccccc}
\hline Konstruk & $\begin{array}{c}\text { Jumlah } \\
\text { indikator }\end{array}$ & $\begin{array}{c}\text { Rata } \\
\text {-rata }\end{array}$ & $\begin{array}{c}\text { Kisaran } \\
\text { Teoritis }\end{array}$ & $\begin{array}{c}\text { Kisaran } \\
\text { Aktual }\end{array}$ & $\begin{array}{c}\text { Dev. } \\
\text { Standar }\end{array}$ \\
\hline $\begin{array}{l}\text { Ukuran } \\
\text { nonfinansial }\end{array}$ & 5 & 19,46 & $5,00-25,00$ & $8,00-25,00$ & 3,79 \\
$\begin{array}{l}\text { Komitmen } \\
\text { organisasi }\end{array}$ & 9 & 30,42 & $9,00-45,00$ & $16,00-45,00$ & 4,63 \\
$\begin{array}{l}\text { Kinerja } \\
\text { manajerial }\end{array}$ & 9 & 32,40 & $9,00-45,00$ & $18,00-45,00$ & 5,03 \\
\hline
\end{tabular}

Sumber: Data olahan peneliti, 2020

Pengujian terhadap korelasi antar variabel laten penelitian dilakukan untuk mengevaluasi keterkaitan antar variabel penelitian dan memberikan gambaran mengenai korelasi atribut untuk tiap-tiap konstruk penelitian. Tabel 2 menunjukkan terdapat hubungan positif yang memadai (cukup kuat) antara konstruk ukuran nonfinansial dengan komitmen organisasi yaitu sebesar 0,643 serta signifikan. Begitu juga korelasi antar variabel komitmen organiasi dengan kinerja manajerial yang menunjukkan nilai positif dan signifikan sebesar 0,721. Tak terkecuali dengan korelasi antara ukuran nonfinansial dengan kinerja yang memiliki hubungan cukup kuat sebesar 0,662 dan signifikan. Nilai tersebut memberikan asumsi awal atas keterdukungan hipotesis karena semua variabel baik itu independent, dependen, dan mediasi memiliki hubungan yang signifikan dan positif. Selain 
itu, pada Tabel 2 juga mengindikasikan bahwa validitas diskriminan konstruk sudah terpenuhi dilihat dari nilai square roots AVE pada kolom diagonal yang lebih tinggi dibandingkan nilai korelasi antar variabelnya.

Tabel 2

Korelasi Antar variable dan Square Roots AVE (Kolom Diagonal)

\begin{tabular}{|c|c|c|c|c|c|c|}
\hline \multirow{2}{*}{ Variabel } & \multirow{2}{*}{ NF } & \multirow{2}{*}{ Kom } & \multirow{2}{*}{ Kin } & \multicolumn{3}{|c|}{ Signifikansi (p-value) } \\
\hline & & & & NF & Kom & Kin \\
\hline $\begin{array}{l}\text { Ukuran } \\
\text { nonfinansial }\end{array}$ & 0,768 & 0,643 & 0,662 & 1,000 & $<0,001$ & $<0,001$ \\
\hline $\begin{array}{l}\text { Komitmen } \\
\text { organisasi }\end{array}$ & 0,643 & 0,802 & 0,721 & $<0,001$ & 1,000 & $<0,001$ \\
\hline $\begin{array}{l}\text { Kinerja } \\
\text { manajerial }\end{array}$ & 0,662 & 0,721 & 0,849 & $<0,001$ & $<0,001$ & 1,000 \\
\hline \multicolumn{7}{|c|}{$\begin{array}{l}\text { Keterangan: NF=Ukuran nonfinansial, Kom=Komitmen organisasi, } \\
\text { Kin=Kinerja manajerial }\end{array}$} \\
\hline
\end{tabular}

Seperti pada penjelasan sebelumnya, evaluasi pertama dalam analysis PLS adalah evaluasi terhadap model pengukuran atau biasa disebut dengan outer model. Evaluasi ini untuk mengetahui validitas (diskriminan dan konvergen) dan reliabilitas konstruk penelitian. Validitas diskriman penelitian sudah dijelaskan pada Tabel 2 yang menunjukkan tidak ada masalah dalam validitas tesebut. Selanjtunya, berdasarkan asumsi PLS, rule of thumbs untuk validitas konvergen adalah dengan melihat nilai loading faktor lebih besar dari 0,70 dan AVE yang ditunjukkan harus melebihi 0,50 (Hair et al., 2016). Tabel 3 menyajikan nilai-nilai loading faktor untuk indikator serta AVE konstruk penelitian yang mengindikasikan bahwa validitas konvergen sudah baik dan sesuai aturan praktis yang dimaksud.

Selanjutnya, evaluasi model pengukuran untuk melihat reliabilitas konstruk penelitian adalah dengan melihat nilai Cronbach's Alpha (CA) dan Composite Reliability (CR) yang ditunuukkan. Aturan praktis yang berlaku adalah nilai CA dan CR harus lebih besar dari 0,70 (Kock, 2013). Pada Tabel 3 juga mengindikasikan bahwa asumsi reliabilitas konstruk penelitian sudah terpenuhi.

Tahapan selanjutnya adalah evaluasi atau analisis terhadap model struktural (inner model). Evaluasi ini dilakukan untuk melihat kekuatan hubungan serta arah antar konstruk penelitian melalui nilai koefisien jalur (path coefficient) masing-masing konstruk serta nilai koefisien determinasi atau $R$-square yang dihasilkan. Analisis model struktural dalam penelitian ini bertujuan untuk menguji pengaruh dari persepsi kepentingan ukuran kinerja nonfinansial terhadap komitmen organisasi dan kinerja manajerial atau dengan kata lain untuk menguji hipotesis penelitian.

Tabel 3

Validitas dan Reliabilitas Penelitian

\begin{tabular}{|c|c|c|c|c|c|}
\hline \multirow{2}{*}{ Variabel } & \multirow{2}{*}{ Indikator } & \multicolumn{2}{|c|}{ Validitas } & \multicolumn{2}{|c|}{ Reliabilitas } \\
\hline & & Loading & AVE & $\mathbf{C A}$ & $\mathbf{C R}$ \\
\hline \multirow{5}{*}{$\begin{array}{l}\text { Ukuran } \\
\text { nonfinansial } \\
\text { (NF) }\end{array}$} & NF1 & 0,750 & \multirow{5}{*}{0,585} & \multirow{5}{*}{0,837} & \multirow{5}{*}{0,784} \\
\hline & NF2 & 0,809 & & & \\
\hline & NF3 & 0,812 & & & \\
\hline & NF4 & 0,832 & & & \\
\hline & NF5 & 0,775 & & & \\
\hline \multirow{9}{*}{$\begin{array}{l}\text { Komitmen } \\
\text { organisasi } \\
\text { (Kom) }\end{array}$} & Koml & 0,721 & \multirow{9}{*}{0,607} & \multirow{9}{*}{0,790} & \multirow{9}{*}{0,865} \\
\hline & Kom2 & 0,748 & & & \\
\hline & Kom3 & 0,802 & & & \\
\hline & Kom4 & 0,711 & & & \\
\hline & Kom5 & 0,820 & & & \\
\hline & Kom6 & 0,846 & & & \\
\hline & Kom7 & 0,842 & & & \\
\hline & Kom8 & 0,778 & & & \\
\hline & Kom9 & 0,819 & & & \\
\hline \multirow{9}{*}{$\begin{array}{l}\text { Kinerja } \\
\text { manajerial } \\
\text { (Kin) }\end{array}$} & Kin1 & 0,723 & \multirow{9}{*}{0,680} & \multirow{9}{*}{0,862} & \multirow{9}{*}{0,775} \\
\hline & Kin2 & 0,746 & & & \\
\hline & Kin 3 & 0,882 & & & \\
\hline & Kin4 & 0,729 & & & \\
\hline & Kin5 & 0,763 & & & \\
\hline & Kin6 & 0,971 & & & \\
\hline & Kin7 & 0,820 & & & \\
\hline & Kin8 & 0,792 & & & \\
\hline & Kin9 & 0,785 & & & \\
\hline
\end{tabular}

Sumber: Output PLS data olahan, 2020

Hasil estimasi terhadap model penelitian untuk melihat kesesuaian model tersebut menunjukkan asumsi goodness of fit yang sudah terpenuhi (Tabel 4). Evaluasi kesesuaian model tersebut dilihat dari kriteria nilai APC dan ARS yang menunjukkan nilai signifikan secara statistik. Selain itu, kriteria lain menurut Hair dkk. (2014) adalah dengan melihat nilai AVIF yang dalam penelitian ini juga memenuhi kriteria di bawah 5,00.

Tabel 4

Luaran Evaluasi Terhadap Model Struktural PLS

\begin{tabular}{|c|c|c|}
\hline Indikator Model Fit & Nilai & p-value \\
\hline $\begin{array}{l}\text { Average Path } \\
\text { Coefficient (APC) }\end{array}$ & 0,367 & $<0,01$ \\
\hline $\begin{array}{l}\text { Average } R \text {-square } \\
\text { (ARS) }\end{array}$ & 0,411 & $<0,01$ \\
\hline AVIF & 2,402 & \\
\hline Jalur & $\begin{array}{c}\text { Koefisien } \\
\text { Jalur }\end{array}$ & $p$-value \\
\hline $\begin{array}{l}\text { Nonfinansial } \rightarrow \text { Komitmen } \\
\text { Organisasi }\end{array}$ & 0,355 & $<0,01$ \\
\hline $\begin{array}{l}\text { Nonfinansial } \rightarrow \text { Kinerja } \\
\text { Manajerial }\end{array}$ & 0,401 & $<0,01$ \\
\hline $\begin{array}{l}\text { Komitmen Organisasi } \rightarrow \text { Kinerja } \\
\text { Manajerial }\end{array}$ & 0,342 & $<0,05$ \\
\hline
\end{tabular}


Selanjutnya, pada Tabel 4 dan Gambar 3 menyediakan hasil pengujian terhadap model penelitian yang menunjukkan nilai koefisien jalur dan $R$-square untuk melihat pengaruh antar variabel dalam model. Dapat terlihar di Gambar 3 yang menunjukkan nilai path coefficient variabel ukuran nonfinansial terhadap komitmen organisasi adalah sebesar 0,355 dan signifikan pada level 0,01 serta 0,401 untuk variabel ukuran nonfinansial terhadap kinerja manajerial. Nilai koefisien jalur yang positif tersebut mengindikasikan adanya pengaruh positif dari ukuran nonfinansial terhadap komitmen organisasi dan kinerja manajerial sekaligus memberikan bukti keterdukungan secara statistik untuk hipotesis 1a dan 1b. Untuk variabel komitmen afektif organsiasi dan kinerja manajerial, nilai path coefficient yang ditunjukkan adalah sebesar 0,342 serta signifikan pada level 0,05. Nilai tersebut membuktikan adanya pengaruh yang positif dari variabel ukuran nonfinansial terhadap kinerja manajerial sekaligus mendukung hipotesis 2 penelitian.

Nilai koefisien diterminan atau $R$-square pada Gambar 3 menunjukkan nilai sebesar $R^{2}=0,33$ untuk konstruk komitmen organisasi. Nilai tersebut menyimpulkan bahwa variasi perubahan dari komitmen organisasi dapat dijelsakan dan disebabkan oleh ukuran kinerja nonfinansial sebesar 33\% dan sekitar $67 \%$ lainnya dijelaskan oleh variabel diluar model penelitian. Sama halnya dengan nilai koefisien determinasi dari konstruk kinerja manajerial yang menunjukkan nilai sebesar $\mathrm{R}^{2}=0,49$. Nilai tersebut menjelaskan bahwa variasi perubahan yang terjadi pada variabel kinerja manajerial dapat dijelaskan oleh ukuran kinerja nonfinansial dan komitmen organsiasi sebanyak $49 \%$.

Berkenaan dengan hipotesis pengaruh tidak langsung penelitian (H3), merujuk dari asumsi yang dikemukakan oleh Baron \& Kenny (1986), adanya peran mediasi atau pengaruh tidak langsung dari variabel intervensi dikatakan terjadi jika variabel independen penelitian memiliki pengaruh yang signifikan terhadap variabel mediasi, begitu juga dengan variabel mediasi yang berpengaruh signifikan terhadap variabel dependen. Dari analisis PLS yang disajikan dalam Gambar 3 dan Tabel 4, variabel ukuran nonfinansial (independen) berpengaruh secara signifikan terhadap komitemen organsiasi $(\beta=0,355$; $p$-value $<0,01)$. Begitu juga dengan variabel mediasi komitmen organisasi yang memiliki pengaruh signifikan terhadap kinerja majaerial (dependen) dengan nilai $\beta=0,342$ dengan $p$-value $<0,05$. Hal ini memberikan bukti kesesuaian hasil analisis dengan asumsi yang dikemukakan oleh Baron \& Kenny (1986) serta menyimpulkan keterdukungan pada hipotesis mediasi (H3) penelitian. Selain itu, Berdasarkan panduan statistik analisis PLS tentang pengujian peran mediasi suatu variabel, peneliti juga menggunakan asumsi terjadinya pengaruh mediasi dalam sebuah model penelitian dengan analisis PLS yang dijelaskan oleh Hair, Hult, Ringle, \& Sarstedt (2016) serta Kock (2013). Langkah pengujian efek mediasi dalam penelitian ini terdiri atas dua tahapan yaitu:

a) Membuat estimasi pengaruh langsung dari variabel indipenden ukuran nonfinansial (NF) terhadap kinerja manajerial (Kin) sebagai variabel dependen,

b) Membuat estimasi analisis pengaruh tidak langsung secara bersamaan melalui triangle PLS model yaitu menghubungkan variabel independen ukuran nonfinansial (NF), variabel mediasi komitmen organisasi (Kom), dan variabel dependen kinerja manajerial (Kin).

Asumsi yang berlaku pada pengujian dan estimasi model mediasi analisis PLS seperti langkah di atas adalah sebagai berikut (Hair et al., 2016):

a) Jika koefisien jalur pengaruh tidak langsung pada langkah kedua (setelah ada variabel mediasi) antara variabel independen dan dependen tidak mengalami perubahan atau sama dengan nilai koefisien jalur pada pengaruh langsung, maka dapat disimpulkan hipotesis mediasi tidak terdukung,

b) Jika koefisien jalur pengaruh tidak langsung pada langkah kedua antara variabel independen dan dependen mengalami penerunan namun masih menunjukkan signifikansi, maka terjadi mediasi dalam bentuk sebagian atau partial mediation,

c) Jika pengaruh langsung antara variabel independent dan dependen setelah terdapat variabel mediasi dalam model menunjukkan nilai yang tidak signifikan dan hubungan langsungnya tetap signifikan, maka dapat disimpulkan bahwa terjadi mediasi penuh (full mediation) dalam hubungan tersebut (Nitzl, Roldan \& Cepeda, 2016).

Gambar 2 dan Gambar 3 di bawah ini menunjukkan hasil analisis dan estimasi dari langkah-langkah pengujian hipotesis mediasi penelitian tersebut. 


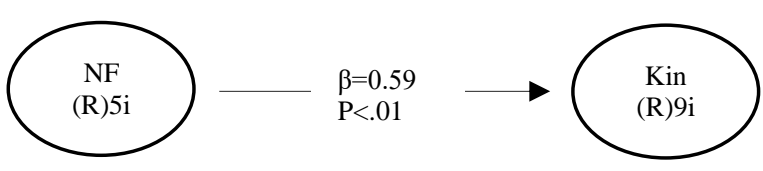

Gambar 2. Estimasi Direct Effect Model PLS Penelitian

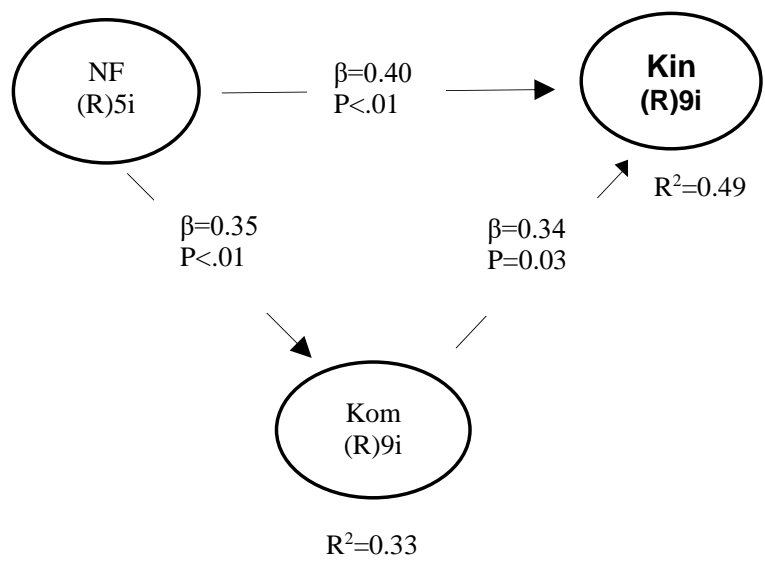

Gambar 3. Estimasi Indirect Effect Model PLS Penelitian

Dari hasil estimasi terhadap model pengaruh langsung dan tidak langsung (Gambar 2 dan Gambar 3), dapat kita lihat bahwa koefisien jalur pengaruh langsung antara ukuran nonfinansial (NF) terhadap kinerja manajerial (Kin) menunjukkan nilai $\beta=0,592$ serta signifikan pada level p-value $<0,01$. Selanjutnya, pada pengaruh tidak langsung (setelah masuk variabel komitmen organisasi dalam model) dapat dilihat bahwa nilai koefisien jalur yang dihasilkan adalah sebesar $\beta=0,401$ dan signifikan pada level 0,01. Berdasarkan peroleh nilai estimasi tersebut, dapat disimpulkan bahwa terjadi penurunan nilai koefisien jalur dari pengaruh langsung ke tidak langsung namun tetap signifikan. Hal ini sejalan dengan asumsi yang kedua (poin b) dalam estimasi pengaruh mediasi di atas sehingga hipotesis mediasi penelitian (H3) yang menyebutkan ukuran kinerja nonfinansial bepengaruh tidak langsung terhadap kinerja manajerial melalui komitmen afektif organiasi dikatakan terdukung.

\section{Pembahasan}

Tujuan dari Penelitian ini adalah berfokus pada bagaimana tingkat kepentingan penggunaan ukuran kinerja nonfinansial balanced scorecard oleh atasan dalam evaluasi kinerja karyawan (manajer) dapat mempengaruhi komitmen organisasi dan peningkatan kinerja para karyawan. Secara garis besarnya, studi ini menginvestigasi (1) pengaruh langsung tingkat kepentingan ukuran nonfinansial terhadap komitmen organsiasi afektif dan kinerja manajerial serta (2) pengaruh tidak langsung ukuran nonfinansial terhadap kinerja manajerial yang dimediasi oleh komitmen organisasi.

Hasil pengujian hipotesis secara keseluruhan (H1a, $\mathrm{H} 1 \mathrm{~b}, \mathrm{H} 2$, dan $\mathrm{H} 3$ ) menunjukkan adanya konsistensi antara hasil dan prediksi dalam penelitian ini. Dengan kata lain, penelitian ini memberikan bukti bahwa secara statistik tingkat kepentingan penggunaan ukuran kinerja nonfinansial untuk evaluasi kinerja memiliki pengaruh langsung terhadap komitmen organisasi karyawan dan kinerja manajerial serta terjadinya pengaruh tidak langsung antara pengaruh antara tingkat kepentingan penggunaan ukuran nonfinansial dengan kinerja manajerial yang dimediasi oleh komitmen organisasi.

Pada hasil pengujian H1a dan H1b, hasil estimasi model penelitian berdasarkan analsisi PLS memberikan indikasi yang signifikan bahwa tingkat kepentingan penggunaan ukuran nonfinansial dalam evluasi kinerja berpengaruh langsung dan positif terhadap komitmen organisasi $(\beta=0,35 ; p$-value < $0,01)$ serta kinerja manajerial $(\beta=0,40 ; p$-value < $0,01)$. Untuk pengujian hipotesis $2(\mathrm{H} 2)$ penelitian, hasil analisis PLS memberikan bukti statistik bahwa terdapat hubungan langsung dan positif antara komitmen organisasi dan kinerja manajerial $(\beta=0,34$; $p$-value < 0,05). Oleh karena itu, hasil pengujian statistik terhadap H1a, H1b, dan $\mathrm{H} 2$ memberikan indikasi empiris terhadap keterdukungan hipotesis yang diajukan. Sama halnya dengan hipotesis mediasi penelitian (H3) yang mengindikasikan bahwa komitmen organisasi memiliki perana mediasi dalam hubungan antara penggunaan ukuran kinerja nonfinansial dengan kinerja manajerial (lihat gambar 3 dan tabel 4).

\section{Kesimpulan, Keterbatasan, dan Implikasi}

\section{Kesimpulan}

Penelitian ini menginvestagi pengaruh penggunaan ukuran kinerja nonfinansial dalam evalausi kinerja karyawan terhadap komitmen organisasi dan kinerja manajerial serta pengaruh tidak langsungnya terhadap kinerja manajerial melalui komitmen organsiasi. Berdasarkan hasil analisis dan oleahan terhadap data dan pembahasan dpada bagian sebelumnya, penelitian ini berkesimpulan bahwa persepsi mengenai tingkat kepentingan penggunaan ukuran nonfinansial dalam 
evaluasi kinerja memiliki pengaruh terhadap komitmen organisasi dan akan meningkatkan level kinerja manajerial. Secara substantif, hasil penelitian juga menunjukkan bahwa terdapat indikasi pengaruh dari penggunaan ukuran nonfinansial secara tidak langsung juga mempengaruhi kinerja manajerial atau pengaruhnya dimediasi oleh komitmen organisasi. Temuan ini sekaligus mengkonfirmasi hasil dari penelitian Lau \& Moser (2008) yang juga menemukan hasil bahwa ukuran kinerja nonfinansial berpengaruh (baik secara langsung maupun tidak langsung) terhadap perilaku dan kinerja individu organsiasi. Namun, penelitian ini cukup berbeda karena menggunaan research-setting berbeda dengan penelitian terdahulu khususnya dalam penggunaan sampel serta demografi yang jauh berbeda. Penelitian ini dilakukan di Indonesia yang masuk dalam kategori emerging economies dan terkadang memiliki hasil yang berbeda dengan penelitian-penelitian yang dilakukan di negara maju (Jermias \& Setiawan, 2008).

Para manajer yang sedang menempuh studi lanjut magister manajemen sebagai sampel dalam peneitian ini menganggap bahwa ukuran kinerja nonfinansial sangat penting untuk digunakan dalam evaluasi kinerja mereka. Penggunaannya dianggap penting karena akan menciptakan komitmen yang besar dalam diri mereka terhadap organisasi atau perusahaan tempat mereka bekerja. Bagitu juga dengan kinerja, melalui penggunaan ukuran nonfinansial dalam evaluasi kinerja, mereka merasa bahwa kinerja mereka akan dievaluasi dengan baik dan akan mengarahkan tindakan dan aktivitas untuk meningkatkan kinerja mereka dalam organisasi.

\section{Implikasi}

Hasil penelitian ini memberikan implikasi penting secara praktis dan teoritis. Penelitian ini membuktikan bahwa penggunaan ukuran kinerja nonfinansial merupakan hal yang penting sebagai karakteristik dalam sistem pengukuran kinerja. Para atasan perlu lebih teliti dan berhati-hati ketika merancang sebuah sistem pengukuran kinerja karena sistem tersebut nantinya bermakna secara esensial bagi karyawan. Oleh karena itu, atasan perlu mengembangkan sistem pengukuran kinerja yang lebih komprehensif dan memasukkan ukuran-ukuram kinerja nonfinansial sebagai karakter penilaian. Selanjutnya, secara teoritis, penelitian ini memberikan kontribusi perluasan literatur dan bukti empiris dengan pengaturan penelitian yang berbeda dari sebelumnya mengenai pengaruh penggunaan ukuran kinerja nonfinansial terhadap perilaku dan kinerja individu organisasi.

\section{Keterbatasan}

Terdapat beberapa keterbatasan yang melekat pada studi ini. Meskipun penelitian ini telah teliti dalam pemilihan sampel yang representatif, bias yang ada dalam metode survei yang digunakan peneliti masih mungkin dapat terjadi. Dalam teknik survei secara cross-sectional cenderung akan terjadi bias metode umum (common method bias) yang mana para responden akan memberikan jawaban yang dipengaruhi oleh jawaban pada pertanyaan sebelumnya. Penelitian kedepan perlu memperhatikan masalah bias ini dengan melakukan pendekatan berbeda dalam mengumpulkan data (misalnya wawancara) atau metode penelitian yang lain. Keterbatasan lainnya adalah terkait cakupan penggunaan atau observasi variabel dalam model penelitian. Peneliti masih terbatas dengan penggunaan variabel mediasi komitmen organisasi sedangkan beberapa literatur akuntansi manajemen memngungkapkan bahwa masih banyak variabel lain yang dapat mengintervensi pengaruh penggunaan ukuran kinerja nonfinansial terhadap kinerja majaerial. Oleh karena itu, perlu ada penelitian lebih lanjut yang memperluas observasinya dengan menggunaan variabel lain untuk mengamati proses pengaruh kedua variabel tersebut tersebut.

\section{Referensi}

Baron, R. M., \& Kenny, D. A. (1986). The moderator-mediator variable distinction in social psychological research: Conceptual, strategic, and statistical considerations. Journal of Personality and Social Psychology, 51(6), 1173-1182. https://doi.org/10.1037/0022-3514.51.6.1173

Bedford, D. S., Bisbe, J., \& Sweeney, B. (2019). Performance measurement systems as generators of cognitive conflict in ambidextrous firms. Accounting, Organizations and Society, 72, 21-37. https://doi.org/10.1016/j.aos.2018.05.010

Behn, R. D. (2003). Why Measure Performance? Different Purposes Require Different Measures. Public Administration Review, 63(5), 586-606. https://doi.org/10.1111/1540-6210.00322

Chenhall, R. H. (2005). Integrative strategic performance measurement systems, strategic alignment of manufacturing, learning and strategic outcomes: an exploratory study. Accounting, Organizations and Society, 30(5), 395-422. https://doi.org/10.1016/j.aos.2004.08.001

Chenhall, R. H., \& Langfield-Smith, K. (2007). Multiple 
Perspectives of Performance Measures. European Management Journal, 25(4), 266-282. https://doi.org/10.1016/j.emj.2007.06.001

Chenhall, R. H., \& Moers, F. (2015). The role of innovation in the evolution of management accounting and its integration into management control. Accounting, Organizations and Society, 47, 1 13. https://doi.org/10.1016/j.aos.2015.10.002

Chow, C. W., \& Van Der Stede, W. A. (2006). The use and usefulness of nonfinancial performance measures. Management Accounting Quarterly, 7(3), 1-9. https://doi.org/10.1093/oxrep/19.2.250

Davis, S., \& Albright, T. (2004). An investigation of the effect of Balanced Scorecard implementation on financial performance. Management Accounting Research, 15(2), 135-153. https://doi.org/10.1016/j.mar.2003.11.001

Grafton, J., Lillis, A. M., \& Widener, S. K. (2010). The role of performance measurement and evaluation in building organizational capabilities and performance. Accounting, Organizations and Society, 35(7), 689-706. https://doi.org/10.1016/j.aos.2010.07.004

Hair, J. F., Hult, T., Ringle, C. M., \& Sarstedt, M. (2016). A primer on partial least squares structural equation modeling (PLS-SEM) (2nd ed.). CA: Sage.

Hall, M. (2008). The effect of comprehensive performance measurement systems on role clarity, psychological empowerment and managerial performance. Accounting, Organizations and Society, $33(2-3)$, https://doi.org/10.1016/j.aos.2007.02.004

Hartmann, F., \& Slapničar, S. (2009). How formal performance evaluation affects trust between superior and subordinate managers. Accounting, Organizations and Society, 34(6-7), 722-737. https://doi.org/10.1016/j.aos.2008.11.004

Hoque, Z. (2014). 20 years of studies on the balanced scorecard: Trends, accomplishments, gaps and opportunities for future research. The British Accounting Review, 46(1), 33-59. https://doi.org/10.1016/j.bar.2013.10.003

Hoque, Z., \& James, W. (2000). Linking Balanced Scorecard Measures to Size and Market Factors: Impact on Organizational Performance. Journal of Management Accounting Research, 12(1), 1-17. https://doi.org/10.2308/jmar.2000.12.1.1

Ittner, C. D., Larcker, D. F., \& Randall, T. (2003). Performance implications of strategic performance measurement in financial services firms. Accounting, Organizations and Society, 28(7-8), 715-741. https://doi.org/10.1016/S0361-3682(03)00033-3

Jaros, S. J., Jermier, J. M., Koehler, J. W., \& Sincich, T. (1993). Effects of continuance, affective, and moral commitment on the withdrawal process: an evaluation of eight structural equation models. Academy of Management Journal, 36(5), 951-995. https://doi.org/10.2307/256642
Jermias, J., \& Setiawan, T. (2008). The moderating effects of hierarchy and control systems on the relationship between budgetary participation and performance. The International Journal of Accounting, 43(3), 268-292. https://doi.org/10.1016/j.intacc.2008.06.009

Kaplan, R. S., \& Norton, D. P. (1996). The balanced scorecard: translating strategy into action. New York: Harvard Business Press.

Kock, N. (2013). Using WarpPLS in E-Collaboration Studies. International Journal of E-Collaboration, 9(3), 1-12. https://doi.org/10.4018/jec.2013070101

Lau, C. M. (2011). Nonfinancial and financial performance measures: How do they affect employee role clarity and performance? Advances in Accounting, 27(2), 286-293. https://doi.org/10.1016/j.adiac.2011.07.001

Lau, C. M., \& Moser, A. (2008). Behavioral Effects of Nonfinancial Performance Measures: The Role of Procedural Fairness. Behavioral Research in Accounting, 20(2), 55-71. https://doi.org/10.2308/bria.2008.20.2.55

Lau, C. M., \& Oger, B. (2012). Behavioral effects of fairness in performance measurement and evaluation systems: Empirical evidence from France. Advances in Accounting, 28(2), 323-332. https://doi.org/10.1016/j.adiac.2012.09.009

Lau, C. M., \& Roopnarain, K. (2014). The effects of nonfinancial and financial measures on employee motivation to participate in target setting. The British Accounting Review, 46(3), 228-247. https://doi.org/10.1016/j.bar.2014.02.006

Locke, E. A., \& Latham, G. P. (1991). A Theory of Goal Setting and Task Performance. The Academy of Management Review, 16(2), 480. https://doi.org/10.2307/258875

Mahoney, T. A., Jerdee, T. H., \& Carroll, S. J. (1965). The Job(s) of Management. Industrial Relations, 4(2), 97-110. https://doi.org/10.1111/j.1468-232X.1965.tb00922.x

Malina, M. A., \& Selto, F. H. (2004). Choice and change of measures in performance measurement models. Management Accounting Research, 15(4), 441-469. https://doi.org/10.1016/j.mar.2004.08.002

Meyer, J. P., Paunonen, S. V., Ian, R., Goffin, R. D., \& Jackson, D. N. (1989). Organizational commitment and job performance: It's the nature of the commitment that counts. Journal of Applied Psychology, 74(1), 152-156.

Mowday, R. T., Steers, R. M., \& Porter, L. W. (1979). The measurement of organizational commitment. Journal of Vocational Behavior, 14(2), 224-247. https://doi.org/10.1016/00018791(79)90072-1

Saputra, P. H., \& Riyanto, B. (2017). The effect of the degree of importance of the use of non financial and financial measures on 
interpesonal trust and managerial job performance. In The 4th Sebelas Maret International Conference on Business, Economics, and Social Sciences (pp. 148-167).

Sholihin, M., \& Pike, R. (2010). Organisational commitment in the police service: exploring the effects of performance measures, procedural justice and interpersonal trust. Financial Accountability \& Management, 26(4), 392-421. https://doi.org/10.1111/j.14680408.2010.00507.x

Supriyadi, S. (2010). The Moderating Effect of Procedural Justice on the Effectiveness of the Balanced Scorecard in Improving Managerial Performance through Organizational Commitment. Gadjah Mada International Journal of Business, 12(3), 415 https://doi.org/10.22146/gamaijb.5507

Ukko, J., Tenhunen, J., \& Rantanen, H. (2007). Performance measurement impacts on management and leadership: Perspectives of management and employees. International Journal of Production Economics, 110(1-2) https://doi.org/10.1016/j.ijpe.2007.02.008 